\title{
Antifungal susceptibility profile of diferent yeasts isolates from wild animals, cow's milk with subclinical mastitis and hospital environment
}

\author{
J. F. Mendes ${ }^{a}$, C. L. Gonçalves ${ }^{b}$, G. F. Ferreira ${ }^{b}$, I. A. Esteves ${ }^{b}$, C. H. Freitas ${ }^{b}$, \\ J. P. V. Villarreal ${ }^{b}$, J. R. B. Mello ${ }^{c}$, M. C. A. Meireles ${ }^{a}$ and P. S. Nascente ${ }^{b}$ \\ aCentro de Pesquisa e Diagnóstico em Micologia Veterinária - MICVET, Departamento de Veterinária Preventiva, \\ Faculdade de Veterinária, Universidade Federal de Pelotas - UFPel, Campus Universitário, s/n, \\ CEP 96160-000, Capão do Leão, RS, Brazil \\ bLaboratório de Micologia e Bioprospecção, Departamento de Microbiologia e Parasitologia, Instituto de Biologia - IB, \\ Universidade Federal de Pelotas - UFPel, Campus Universitário, s/n, CEP 96160-000, Capão do Leão, RS, Brazil \\ 'Departamento de Farmacologia, Instituto de Ciências Básicas da Saúde, Universidade Federal do Rio Grande do Sul - \\ UFRGS, Sarmento Leite, 500/200, Cidade Baixa, CEP 90050-170, Porto Alegre, RS, Brazil \\ *e-mail: josiara.mds@hotmail.com
}

Received: April 8, 2016 - Accepted: August 12, 2016 - Distributed: February 28, 2018

\begin{abstract}
Yeast infections have acquired great importance due to increasing frequency in immunocompromised patients or patients undergoing invasive diagnostic and therapeutic techniques, and also because of its high morbidity and mortality. At the same time, it has been seen an increase in the emergence of new pathogenic species difficult to diagnose and treat. The aim of this study was to determine the in vitro susceptibility of 89 yeasts from different sources against the antifungals amphotericin B, voriconazole, fluconazole and flucytosine, using the VITEK ${ }^{\circledR} 2$ Compact system. The antifungal susceptibility was performed automatically by the Vitek ${ }^{\circledR} 2$ Compact system. The origin of the yeasts was: Group 1 - microbiota of wild animals (W) (26/89), 2 - cow's milk with subclinical mastitis (M) (27/89) and 3 - hospital enviorment $(\mathrm{H})(36 / 89)$. Of the 89 yeasts submitted to the Vitek ${ }^{\circledR} 2$ test, $25(20.9 \%)$ were resistant to fluconazole, $11(12.36 \%)$ to amphotericin B, $3(3.37 \%)$ to voriconazole, and no sample was resistant to flucytosine. Regarding the minimum inhibitory concentration (MIC), fluconazole showed an MIC between 1 and $64 \mathrm{mg} / \mathrm{mL}$ for the three groups, voriconazole had an MIC between 0.12 and $8 \mathrm{mg} / \mathrm{mL}$, amphotericin B had an MIC between 0.25 and $4 \mathrm{mg} / \mathrm{mL}$ for group $\mathrm{H}$ and group $\mathrm{W}$ respectively, between 0.25 and $16 \mathrm{mg} / \mathrm{mL}$ for group $\mathrm{M}$ and flucytosine had an MIC equal to $1 \mu \mathrm{g} / \mathrm{mL}$ for all groups. The yeasts isolated from the $\mathrm{H}$ group showed the highest resistance to fluconazole $12 / 89(13.49 \%)$, followed by group $\mathrm{W}(7.87 \%)$ and group $\mathrm{M}(5.62 \%)$. The more resistant group to voriconazole was followed by the $\mathrm{M}$ and $\mathrm{H}$ groups, the $\mathrm{W}$ group showed no resistance to this antifungal. Group $\mathrm{H}$ was the least resistant $(2.25 \%)$ to amphotericin.
\end{abstract}

Keywords: antifungal, yeast, Vitek ${ }^{\circledR} 2$ Compact.

\section{Perfil de suscetibilidade antifúngica de diferentes leveduras isoladas da microbiota de animais silvestres, leite com mastite subclínica e ambiente hospitalar}

\footnotetext{
Resumo

As infecções por leveduras têm adquirido grande importância, devido ao aumento da sua frequência em pacientes imunocomprometidos ou pacientes submetidos a técnicas diagnosticas e terapêuticas agressivas, e devido sua alta morbidade e mortalidade. Paralelamente tem-se observado um incremento na aparição de novas espécies patógenas difíceis de diagnosticar e tratar. O objetivo desse estudo foi avaliar a suscetibilidade in vitro de 89 leveduras de diferentes origens frente aos antifúngicos Anfotericina B, Voriconazol, Fluconazol e Fluocitocina pelo Sistema Vitek ${ }^{\circledR} 2$. $\mathrm{O}$ antifungigrama foi realizado automaticamente pelo Vitek ${ }^{\circledR} 2$ Compact. A origem das leveduras foi: Grupo 1-Microbiota de Animais Silvestres (S) (26/89), 2- Leite com mastite bovina subclínica (L) (27/89) e 3- Ambiente Hospitalar (H) (36/89). Das 89 leveduras submetidas à carta Vitek ${ }^{\circledR}, 25$ (20.09\%) foram resistentes ao fluconazol, oito (8.99\%) à anfotericina B, três (3.37\%) ao voriconazol, e nenhuma amostra mostrou-se resistente a fluocitosina. O grupo três (H) foi mais resistente ao fluconazol que os demais, já o dois (L) foi mais resistente ao voriconazol e a anfotericina $\mathrm{B}$ que
} 
os outros dois. O fluconazol pode ter apresentado maior número de resistências devido ser um fármaco comumente usado principalmente em humanos. As leveduras isoladas de humanos apresentaram maior número de resistências aos fármacos testados do que as leveduras isoladas de animais silvestres. O que pode ocorrer devido a uma maior exposição dos humanos aos fármacos em relação aos animais que vivem isolados em ambientes selvagens e na maioria dos casos nunca teve contato com fármacos de qualquer origem.

Palavras-chave: antifúngicos, leveduras, Vitek ${ }^{\circledR} 2$ Compact.

\section{Introduction}

Fungi are microorganisms found in soil, water, vegetables, air, animals and detritus. Many of them have a pathogenic potential to human and animals causing diseases known as mycoses (Trabulsi and Toledo, 1991). The infections caused by fungi had acquired importance in the last decades, not only due to an increase in its frequency in immunocompromised or submitted patients undergoing through aggressive diagnostic techniques and therapeutic treatments, but also due to its high morbidity and mortality. Meanwhile an increase in the emergence of new pathogenic species difficult to diagnose and treat has been observed (Coleman et al., 2008); this increase is not only due to the frequent use of antifungal drugs to treat these kinds of infections but also due to therapeutic drug overdose. This resistance, especially in azole derivatives has been previously described, demonstrating the need of in vitro susceptibility studies to evaluate the efficacy of antifungals drugs, before starting a treatment (Sandven, 2000).

Among different fungi species, the gender Candida spp., is responsible for around $80 \%$ of all nosocomial fungal infections (Spellberg et al., 2006). Candida albicans is the most predominant specie present in about $50 \%$ of all the isolates, followed by C. glabrata, C. parapsilosis and $C$. tropicalis present in around 10 to $25 \%$ respectively. In Latin America, C. parapsilosis figures as the second cause of the mycoses (Spellberg et al., 2006; Höfling et al., 2010).

The antifungal resistance has represented a major challenge for the clinic, by the difficulty to treat candidiasis. The increase of the antifungal resistance may be due to the use of selective therapies with inadequate doses or to the drug's frequent use in the fungal infection prophylaxis, both in human and animals, which may affect the selective clinical resistance (Colombo and Guimarães, 2007; Galle and Gianinni, 2009).

The Vitek ${ }^{\circledR} 2$ Compact system is an automatized commercial method for antifungal susceptibility analyses, which determinates the spectrophotometric yeast growth allowing the identification of different species, comparing the biochemical profile with a wide data base (Al-Sweih et al., 2009; Mokaddas et al., 2007). This system also incorporates the AST- YS01 plate, which is used to test the yeast against the following antifungal drugs: Amphotericin B, Voriconazole, Fluconazole and Flucytosine.

Once the plate is placed inside the Vitek ${ }^{\circledR} 2$ Compact system device, using an adequate microorganism suspension, the manipulation it's not necessary. Once the dilutions are made, the plate is inoculated using a vacuum filling process, then is sealed and placed automatically in the reader/incubator (bioMérieux, 2008). The system integrates a software that validates and interprets the susceptibility test results and determinates them automatically. The growth is based on the measure of the decreased light by an optic scanner. This data is used to determinate the minimum inhibitory concentration (MIC) values of the antifungal drugs tested (Pfaller et al., 2011).

The aim of this study was to evaluate the in vitro susceptibility of 89 yeasts from different origins against the following antifungal drugs: Amphotericin B, Voriconazole, Fluconazole and Flucytosine using the Vitek ${ }^{\circledR} 2$ Compact system.

\section{Material and Methods}

Eighty-nine different isolated yeasts were evaluated. Yeasts were obtained from the mycology collection of Mycology Laboratory in the Department of Microbiology and Parasitology located in the Biology Institute from the Federal University of Pelotas.

The yeasts isolates were identify and grouped in eight fungal genera, each one with their respective species: Candida albicans (11), C. guilliermondii (14), C. famata (10), C. parapsilosis (10), C. ciferri (4), C. catenulata (2), C. sphaerica (2), C. intermedia (2), C. pulcherrima (2), C. rugosa (1), C. peliculosa (1), C. lipolytica (1), C. globosa (1), Cryptococcus laurentii (9), Trichosporon asahii (2), Trichosporon sp. (1), Sacharomyces sp. (1), S. cerevisiae (3), Geotrichum klebahnii (2), Zigossacharomyces sp. (1), Rhodotorula sp. (8) and Kodamala ohmeri (1).

The yeasts used in this study were obtained and isolated from different places and distributed in three different groups: Group 1- Isolates from the wild animals microbiota (W) (26) 29.21\%; Group 2- Isolates from cow's milk with subclinical mastitis (M) (27) $30.34 \%$ and Group 3- Isolates from human Hospital environment $(\mathrm{H})$ (36) $41.57 \%$ (Intensive Care Unit).

The antifungal susceptibility was performed automatically using the Vitek ${ }^{\circledR} 2$ Compact system. This device was handled according to the manufacturer's instructions. The yeasts, previously stored, were replicated in Sabouraud Dextrose Agar with Chloramphenicol by the depletion technique and incubated at $36^{\circ} \mathrm{C} / 48 \mathrm{~h}$. After this period the suspensions were made from isolated colonies in disposable tubes containing $3 \mathrm{~mL}$ of $0.45 \%$ Saline Solution adjusted to a $0.5 \mathrm{McFarland}$ standard. To perform the test, the plates 
containing the four antifungal drugs were added and inserted in the equipment.

For the antifungal susceptibility test, the $\operatorname{Vitek}^{\circledR} 2$ compact system follows the Clinical and Laboratory Standars Institute (CLSI), European Society of Clinical Microbiology and Infectious Diseases (EUCAST) and Food and Drug Administration (FDA) international standards. In this test, the Vitek ${ }^{\circledR} 2$ device was configured according to the CLSI documents.

The card of Vitek ${ }^{\circledR} 2$ - AST - YS01 (Lote 281223610), suitable for the realization of antifungal sensitivity tests are disposable and has four drugs at different concentrations (different dilutions): flucytosine (sensitivity $\leq 1 \mu \mathrm{g} / \mathrm{mL}$ ), voriconazole (sensitivity $0.125 \mu \mathrm{g} / \mathrm{mL}$, intermediate sensitivity 2 to $4 \mu \mathrm{g} / \mathrm{mL}$, resistant $\geq 4 \mu \mathrm{g} / \mathrm{mL}$ ), amphotericin B (sensitivity $\leq 0.25 \mu \mathrm{g} / \mathrm{mL}$, intermediate sensitivity 4 to $8 \mu \mathrm{g} / \mathrm{mL}$, resistant $\geq 16 \mu \mathrm{g} / \mathrm{mL}$ ) and fluconazole (sensitivity $\leq 2 \mu \mathrm{g} / \mathrm{mL}$, intermediate sensitivity 14 to $\geq 32 \mu \mathrm{g} / \mathrm{mL}$, resistant $\geq 64 \mu \mathrm{g} / \mathrm{mL}$ ). After the loaded plates were placed in the Vitek 2 instrument, the plates were filled with the appropriately diluted yeast suspensions, incubated (for a maximum of $24 \mathrm{~h}$ ), and reading automatically.

The breakpoints according to CLSI M27 S4 (for Candida spp.) for fluconazole are sensitivity $\leq 2$, susceptible-dose dependent (SDD) 4 to $\geq 32$ and resistant 8 to $\geq 64$, for voriconazole are sensitivity $\leq 0.12$, SDD 0.25 to 1 and resistant $\geq 1$ (CLSI, 2012).

The Vitek $^{\circledR} 2$ Compact system was also used to perform the yeasts biochemical characterization (assimilation of carbohydrates) and to confirm the identification of the species. For the identification of the species, 64 biochemical tests were performed by measuring the use of carbon and nitrogen sources and by the enzymatic activity as well. The final results were obtained in nearly (average) 18 hours. For the statistical analyses, the chi-square test was performed through the use of the SPSS program.

\section{Results}

Among the 89 yeasts submitted to the Vitek ${ }^{\circledR}$ card AST, $85(95.5 \%)$ were susceptible to the flucytosine, $71(79.7 \%)$ to the voriconazole, $71(79.7 \%)$ to the amphotericin B and $52(58.43 \%)$ to the fluconazole. According to resistance, $25(20.09 \%)$ were resistant to the fluconazole, $11(12.36 \%)$ to the amphotericin B, $3(3.37 \%)$ to the voriconazole and no sample revealed resistance to the flucytosine. Regarding to the intermediate sensitivity, eight samples $(8.99 \%)$ were intermediary sensitive to the fluconazole, four $(4.49 \%)$ to the voriconazole, four $(4.49 \%)$ to the amphotericin B and no sample was intermediary sensitive to the flucytosine. The rest of the yeasts did not present resistance results, four (4.49\%) to the flucytosine, two $(2.25 \%)$ to the fluconazole, $11(12.36 \%)$ to the voriconazole and three $(3.37 \%)$ to the amphotericin B, as described in Table 1 .

The higher antifungals action spectrum is shown in the following decreasing order: For the flucytosine the susceptibility rate was of $95.5 \%$, for the voriconazole $80 \%$, for the amphotericin B $80 \%$ and for the fluconazole $58.8 \%$. For the flucytosine, the most susceptible species were: C. guilliermondii, C. albicans, C. parapsilosis and $C$. famata. The voriconazole presented the genera Candida spp. as the most susceptible inside this group, and Rhodotorula sp. being the higher resistance sample. C. laurenti, showed high susceptibility rates against the fluconazole. Meanwhile the genera Candida spp. presented susceptibility variations rates against the amphotericin B, dividing the species inside this genus in two groups: One group having the susceptible species such as C. guiiliermondii, C. parapsilosis and C. albicans, and the other group having the resistant species such as C. ciferri, C. famata and C. albicans.

It has been observed a significant difference between the drugs susceptibility profiles and the fungal specie $(\mathrm{p}<0.05)$ according with the statistical analyses performed through the chi-square test. The resistance results and the origin of the submitted samples to the tests can be described in Table 2, showing that the isolated yeasts from human

Table 1. Origin and susceptibility of 89 yeasts tested against four antifungals by Vitek ${ }^{\circledR} 2$ System.

\begin{tabular}{ccclcccc}
\hline $\mathbf{N}$ & Identification & Origin & \multicolumn{1}{c}{ Species } & Flucytosine & Fluconazole & Voriconazole & Amphotericin B \\
\hline $\mathbf{1}$ & LMI 010 & $\mathrm{H}$ & C. albicans & $\mathrm{S}$ & $\mathrm{S}$ & $\mathrm{S}$ & $\mathrm{S}$ \\
$\mathbf{2}$ & LMI 013 & $\mathrm{H}$ & C. lipolytica & $\mathrm{S}$ & $\mathrm{S}$ & $\mathrm{S}$ & $\mathrm{S}$ \\
$\mathbf{3}$ & LMI 023 & $\mathrm{H}$ & C. laurenti & $\mathrm{S}$ & $\mathrm{S}$ & $\mathrm{S}$ & $\mathrm{S}$ \\
$\mathbf{4}$ & LMI 026 & $\mathrm{H}$ & C. laurentti & $\mathrm{S}$ & $\mathrm{S}$ & $\mathrm{S}$ & $\mathrm{S}$ \\
$\mathbf{5}$ & LMI 028 & $\mathrm{H}$ & T. assahi & $\mathrm{S}$ & $\mathrm{I}$ & $\mathrm{S}$ & $\mathrm{I}$ \\
$\mathbf{6}$ & LMI 127 & $\mathrm{H}$ & Rhodotorula sp. & $\mathrm{S}$ & $\mathrm{R}$ & $\mathrm{I}$ & $\mathrm{S}$ \\
$\mathbf{7}$ & LMI 029 & $\mathrm{H}$ & C. famata & $\mathrm{S}$ & $\mathrm{S}$ & $\mathrm{S}$ & $\mathrm{S}$ \\
$\mathbf{8}$ & LMI 012 & $\mathrm{H}$ & C. guilliermondii & $\mathrm{S}$ & $\mathrm{R}$ & $\mathrm{S}$ & $\mathrm{S}$ \\
$\mathbf{9}$ & LMI 145 & $\mathrm{H}$ & C. albicans & $\mathrm{S}$ & $\mathrm{S}$ & $\mathrm{S}$ & $\mathrm{S}$ \\
$\mathbf{1 0}$ & LMI 136 & $\mathrm{H}$ & C. laurentii & $\mathrm{S}$ & $\mathrm{S}$ & $\mathrm{S}$ & $\mathrm{S}$ \\
$\mathbf{1 1}$ & LMI 151 & $\mathrm{H}$ & C.laurentii & $\mathrm{S}$ & $\mathrm{S}$ & $\mathrm{S}$ & $\mathrm{S}$ \\
$\mathbf{1 2}$ & LMI 157 & $\mathrm{H}$ & C. laurentii & $\mathrm{S}$ & $\mathrm{I}$ & $\mathrm{S}$ & $\mathrm{S}$ \\
$\mathbf{1 3}$ & LMI 158 & $\mathrm{H}$ & C. laurentii & $\mathrm{S}$ & $\mathrm{S}$ & - & $\mathrm{S}$ \\
\hline
\end{tabular}

$\mathrm{R}=$ Resistant; $\mathrm{S}=$ Sensitive; I= Intermediate sensitivity; $\mathrm{W}=$ Wild animal; $\mathrm{M}=$ Milk; $\mathrm{H}=$ Hospital setting. 
Table 1. Continued...

\begin{tabular}{|c|c|c|c|c|c|c|c|}
\hline $\mathbf{N}$ & Identification & Origin & Species & Flucytosine & Fluconazole & Voriconazole & Amphotericin B \\
\hline 14 & LMI 159 & $\mathrm{H}$ & C. laurentii & $\mathrm{S}$ & $\mathrm{S}$ & - & $\mathrm{S}$ \\
\hline 15 & LMI 142 & $\mathrm{H}$ & C. laurentii & $\mathrm{S}$ & $\mathrm{R}$ & - & S \\
\hline 16 & LMI 153 & $\mathrm{H}$ & C. famata & $\mathrm{S}$ & $\mathrm{S}$ & $\mathrm{S}$ & $\mathrm{S}$ \\
\hline 17 & LMI 156 & $\mathrm{H}$ & C. famata & $\mathrm{S}$ & $\mathrm{S}$ & $\mathrm{S}$ & $\mathrm{R}$ \\
\hline 18 & LMI 131 & $\mathrm{H}$ & S. cerevisae & $\mathrm{S}$ & $\mathrm{S}$ & $\mathrm{S}$ & $\mathrm{S}$ \\
\hline 19 & LMI 132 & $\mathrm{H}$ & S. cerevisae & $\mathrm{S}$ & I & $\mathrm{S}$ & $\mathrm{S}$ \\
\hline 20 & LMI 143 & $\mathrm{H}$ & S. cerevisae & $\mathrm{S}$ & $\mathrm{R}$ & $\mathrm{S}$ & $\mathrm{R}$ \\
\hline 21 & LMI 133 & $\mathrm{H}$ & C. parapsilosis & $\mathrm{S}$ & $\mathrm{S}$ & $\mathrm{S}$ & $\mathrm{S}$ \\
\hline 22 & LMI 134 & $\mathrm{H}$ & C. parapsilosis & $\mathrm{S}$ & $\mathrm{S}$ & $\mathrm{S}$ & $\mathrm{S}$ \\
\hline 23 & LMI 135 & $\mathrm{H}$ & C. parapsilosis & $\mathrm{S}$ & $\mathrm{S}$ & $\mathrm{S}$ & $\mathrm{S}$ \\
\hline 24 & LMI 139 & $\mathrm{H}$ & C. parapsilosis & $\mathrm{S}$ & $\mathrm{R}$ & $\mathrm{S}$ & $\mathrm{S}$ \\
\hline 25 & LMI 130 & $\mathrm{H}$ & C. parapsilosis & $\mathrm{S}$ & $\mathrm{R}$ & $\mathrm{S}$ & $\mathrm{S}$ \\
\hline 26 & LMI 125 & $\mathrm{H}$ & C. guilliermondii & $\mathrm{S}$ & $\mathrm{S}$ & $\mathrm{S}$ & $\mathrm{S}$ \\
\hline 27 & LMI 126 & $\mathrm{H}$ & C. guilliermondii & $\mathrm{S}$ & $\mathrm{S}$ & $\mathrm{S}$ & $\mathrm{S}$ \\
\hline 28 & LMI 150 & $\mathrm{H}$ & C. guilliermondii & $\mathrm{S}$ & $\mathrm{R}$ & $\mathrm{S}$ & $\mathrm{S}$ \\
\hline 29 & LMI 154 & $\mathrm{H}$ & C. ciferri & $\mathrm{S}$ & $\mathrm{S}$ & $\mathrm{S}$ & $\mathrm{S}$ \\
\hline 30 & LMI 155 & $\mathrm{H}$ & C. ciferri & S & $\mathrm{R}$ & $\mathrm{S}$ & I \\
\hline 31 & LMI 114 & $\mathrm{H}$ & $\begin{array}{l}\text { Zygosacharomyces } \\
\text { sp. }\end{array}$ & $\mathrm{S}$ & I & $\mathrm{S}$ & $\mathrm{S}$ \\
\hline 32 & LMI 137 & $\mathrm{H}$ & Rhodotorula sp. & $\mathrm{S}$ & I & $\mathrm{S}$ & S \\
\hline 33 & LMI 144 & $\mathrm{H}$ & Rhodotorula $\mathrm{sp}$ & - & - & - & - \\
\hline 34 & LMI 141 & $\mathrm{H}$ & Rhodotorula $\mathrm{sp}$ & - & $\mathrm{R}$ & $\mathrm{S}$ & $\mathrm{S}$ \\
\hline 35 & LMI 129 & $\mathrm{H}$ & Rhodotorula $\mathrm{sp}$ & $\mathrm{S}$ & $\mathrm{R}$ & $\mathrm{R}$ & $\mathrm{S}$ \\
\hline 36 & LMI 047 & M & C. rugosa & $\mathrm{S}$ & $\mathrm{R}$ & I & I \\
\hline 37 & LMI 122 & M & C. albicans & $\mathrm{S}$ & I & $\mathrm{R}$ & $\mathrm{R}$ \\
\hline 38 & LMI 124 & M & C. albicans & $\mathrm{S}$ & $\mathrm{S}$ & $\mathrm{S}$ & $\mathrm{S}$ \\
\hline 39 & LMI 046 & M & C. laurentii & $\mathrm{S}$ & $\mathrm{S}$ & - & $\mathrm{S}$ \\
\hline 40 & LMI 040 & M & Trichosporon sp. & - & - & - & - \\
\hline 41 & LMI 045 & M & C. famata & $\mathrm{S}$ & $\mathrm{S}$ & $\mathrm{S}$ & I \\
\hline 42 & LMI 075 & M & C. famata & $\mathrm{S}$ & $\mathrm{S}$ & $\mathrm{S}$ & $\mathrm{S}$ \\
\hline 43 & LMI 120 & M & C. famata & $\mathrm{S}$ & $\mathrm{R}$ & $\mathrm{R}$ & $\mathrm{R}$ \\
\hline 44 & LMI 038 & M & Sacharomyces sp. & $\mathrm{S}$ & $\mathrm{S}$ & S & $\mathrm{S}$ \\
\hline 45 & LMI 048 & M & C. parapsilosis & $\mathrm{S}$ & $\mathrm{S}$ & $\mathrm{S}$ & $\mathrm{S}$ \\
\hline 46 & LMI 067 & M & C. parapsilosis & $\mathrm{S}$ & $\mathrm{S}$ & $\mathrm{S}$ & $\mathrm{S}$ \\
\hline 47 & LMI 068 & M & C. parapsilosis & $\mathrm{S}$ & $\mathrm{S}$ & $\mathrm{S}$ & $\mathrm{S}$ \\
\hline 48 & LMI 070 & M & C. parapsilosis & $\mathrm{S}$ & $\mathrm{S}$ & $\mathrm{S}$ & $\mathrm{S}$ \\
\hline 49 & LMI 058 & M & C. parapsilosis & $\mathrm{S}$ & $\mathrm{S}$ & $\mathrm{S}$ & $\mathrm{S}$ \\
\hline 50 & LMI 133 & M & C. parapsilosis & $\mathrm{S}$ & $\mathrm{S}$ & S & $\mathrm{S}$ \\
\hline 51 & LMI 134 & M & C. parapsilosis & $\mathrm{S}$ & $\mathrm{S}$ & $\mathrm{S}$ & $\mathrm{S}$ \\
\hline 52 & LMI 135 & M & C. parapsilosis & $\mathrm{S}$ & $\mathrm{S}$ & $\mathrm{S}$ & $\mathrm{S}$ \\
\hline 53 & LMI 139 & M & C. parapsilosis & $\mathrm{S}$ & $\mathrm{R}$ & $\mathrm{S}$ & $\mathrm{S}$ \\
\hline 54 & LMI 130 & M & C. parapsilosis & $\mathrm{S}$ & $\mathrm{R}$ & $\mathrm{S}$ & $\mathrm{S}$ \\
\hline 55 & LMI 050 & M & C. pulcherrima & $\mathrm{S}$ & $\mathrm{S}$ & $\mathrm{S}$ & $\mathrm{S}$ \\
\hline 56 & LMI 071 & M & C. pulcherrima & $\mathrm{S}$ & $\mathrm{R}$ & $\mathrm{S}$ & $\mathrm{S}$ \\
\hline 57 & LMI 054 & M & C. guilliermondii & $\mathrm{S}$ & $\mathrm{S}$ & $\mathrm{S}$ & $\mathrm{S}$ \\
\hline 58 & LMI 055 & M & C. guilliermondii & $\mathrm{S}$ & $\mathrm{S}$ & $\mathrm{S}$ & $\mathrm{S}$ \\
\hline 59 & LMI 056 & M & C. guilliermondii & S & I & $\mathrm{S}$ & $\mathrm{S}$ \\
\hline 60 & LMI 057 & M & C. guilliermondii & $\mathrm{S}$ & $\mathrm{S}$ & $\mathrm{S}$ & $\mathrm{S}$ \\
\hline 61 & LMI 059 & M & C. guilliermondii & $\mathrm{S}$ & I & S & $\mathrm{S}$ \\
\hline 62 & LMI 062 & M & C. guilliermondii & $\mathrm{S}$ & I & $\mathrm{S}$ & $\mathrm{S}$ \\
\hline 63 & LMI 063 & M & C. guilliermondii & $\mathrm{S}$ & $\mathrm{S}$ & $\mathrm{S}$ & $\mathrm{S}$ \\
\hline
\end{tabular}

$\mathrm{R}=$ Resistant; $\mathrm{S}=$ Sensitive; $\mathrm{I}=$ Intermediate sensitivity; $\mathrm{W}=$ Wild animal; $\mathrm{M}=$ Milk; $\mathrm{H}=$ Hospital setting. 
Table 1. Continued...

\begin{tabular}{|c|c|c|c|c|c|c|c|}
\hline $\mathbf{N}$ & Identification & Origin & Species & Flucytosine & Fluconazole & Voriconazole & Amphotericin B \\
\hline 64 & LMI 064 & $\mathrm{M}$ & C. guilliermondii & $\mathrm{S}$ & $\mathrm{S}$ & $\mathrm{S}$ & $\mathrm{S}$ \\
\hline 65 & LMI 061 & M & C. peliculosa & S & I & S & S \\
\hline 66 & LMI 037 & M & Rhodotorula sp. & S & $\mathrm{R}$ & S & $\mathrm{R}$ \\
\hline 67 & LMI 076 & M & K. ohmeri & $\mathrm{S}$ & $\mathrm{R}$ & I & $\mathrm{R}$ \\
\hline 68 & LPS 022 & W & T. assahi & S & $\mathrm{R}$ & $\mathrm{S}$ & S \\
\hline 69 & LMI 091 & W & C. albicans & S & $\mathrm{S}$ & S & S \\
\hline 70 & LMI 092 & W & C. albicans & S & $\mathrm{S}$ & $\mathrm{S}$ & S \\
\hline 71 & LMI 104 & W & C. albicans & S & $\mathrm{S}$ & S & S \\
\hline 72 & LPS 005 & W & C. albicans & S & $\mathrm{S}$ & $\mathrm{S}$ & S \\
\hline 73 & LMI 098 & W & C. albicans & S & $\mathrm{R}$ & S & S \\
\hline 74 & LMI 102 & W & C. albicans & S & $\mathrm{R}$ & $\mathrm{S}$ & S \\
\hline 75 & LMI 081 & W & C. albicans & $\mathrm{S}$ & $\mathrm{R}$ & $\mathrm{S}$ & $\mathrm{R}$ \\
\hline 76 & LPS 009 & W & C. famata & S & $\mathrm{S}$ & S & S \\
\hline 77 & LMI 088 & W & C. famata & S & $\mathrm{R}$ & S & $\mathrm{R}$ \\
\hline 78 & LPS 008 & W & C. guilliermondii & S & S & $\mathrm{S}$ & S \\
\hline 79 & LMI 107 & W & G. klebahnii & $\mathrm{S}$ & $\mathrm{S}$ & $\mathrm{S}$ & $\mathrm{S}$ \\
\hline 80 & LPS 016 & W & G. klebahnii & $\mathrm{S}$ & $\mathrm{S}$ & $\mathrm{S}$ & S \\
\hline 81 & LPS 004 & W & Rhodotorula sp. & S & I & S & S \\
\hline 82 & LMI 117 & W & Rhodotorula sp. & $\mathrm{S}$ & $\mathrm{R}$ & $\mathrm{S}$ & $\mathrm{S}$ \\
\hline 83 & LPS 007 & W & C. sphaerica & S & $\mathrm{S}$ & S & S \\
\hline 84 & LMI 094 & W & C. sphaerica & - & $\mathrm{R}$ & I & - \\
\hline 85 & LMI 101 & W & C. intermedia & S & $\mathrm{S}$ & S & S \\
\hline 86 & LPS 014 & W & C. intermedia & $\mathrm{S}$ & $\mathrm{S}$ & $\mathrm{S}$ & $\mathrm{S}$ \\
\hline 87 & LPS 006 & W & C. catenulata & S & $\mathrm{S}$ & S & S \\
\hline 88 & LMI 084 & W & C. catenulata & S & $\mathrm{R}$ & S & $\mathrm{S}$ \\
\hline 89 & LPS 024 & W & C. globosa & S & $\mathrm{S}$ & $\mathrm{S}$ & $\mathrm{S}$ \\
\hline
\end{tabular}

$\mathrm{R}=$ Resistant; $\mathrm{S}=$ Sensitive; I= Intermediate sensitivity; $\mathrm{W}=$ Wild animal; $\mathrm{M}=$ Milk; $\mathrm{H}=$ Hospital setting.

Table 2. Profile susceptibilidad of yeasts from different Origin against them antifungal fluconazole, Flucytosine, voriconazole and amphotericin B obtained by the Vitek 2 System.

\begin{tabular}{|c|c|c|c|c|c|c|c|c|c|c|c|c|}
\hline & \multicolumn{3}{|c|}{ FLUCONAZOLE (\%) } & \multicolumn{3}{|c|}{ FLUCYTOSINE(\%) } & \multicolumn{3}{|c|}{ VORICONAZOLE (\%) } & \multicolumn{3}{|c|}{ AMPHOTERICIN B (\%) } \\
\hline & $\mathbf{I}$ & $\mathbf{R}$ & $\mathbf{S}$ & $\mathbf{I}$ & $\mathbf{R}$ & $\mathbf{S}$ & $\mathbf{I}$ & $\mathbf{R}$ & $\mathbf{S}$ & I & $\mathbf{R}$ & $\mathbf{S}$ \\
\hline $\mathbf{W}$ & 0.89 & 7.87 & 19.10 & - & - & 26.97 & 0.89 & - & 26.97 & - & 3.37 & 20.22 \\
\hline $\mathbf{M}$ & 5.62 & 5.62 & 17.98 & - & - & 37.08 & 2.25 & 2.25 & 23.60 & 2.25 & 4.49 & 22.47 \\
\hline $\mathbf{H}$ & 7.68 & 13.49 & 21.35 & & - & 28.09 & 1.78 & 1.78 & 25.84 & 1.78 & 2.25 & 34.84 \\
\hline
\end{tabular}

$\mathrm{R}=$ Resistant; $\mathrm{S}=$ Sensitive; I= Intermediate sensitivity.

hospitalary environment presented the higher resistance to the fluconazole $12 / 89(13.49 \%)$ and the higher susceptibility to the flucytosine $(100 \%)$. The isolated yeasts from cow's milk with subclinical mastitis presented a higher resistance to the amphotericin B 4/89 (4.49\%) and to the voriconazole $2 / 89(2.25 \%)$, and also a higher susceptibility to the flucytosine $(100 \%)$. The isolated yeasts from the wild animal's microbiota showed a high resistance to the fluconazole $7 / 89$ (7.87\%), followed by the amphotericin B 3/89 (3.37\%) and both were 100\% susceptible to the flucytosine and the voriconazole, Which demonstrates that human isolated yeasts had a major resistance than the yeasts isolated from wild animals to the antifungals used.

Analysis of the minimum inhibitory concentration (MIC) showed that Fluconazole MIC varies between 1 and $64 \mu \mathrm{g} / \mathrm{mL}$ in the three groups, the voriconazole
MIC rates between 0.12 and $8 \mu \mathrm{g} / \mathrm{mL}$ in the $\mathrm{H}$ group, between 0.12 and $2 \mu \mathrm{g} / \mathrm{mL}$ in the $\mathrm{S}$ group and between 0.12 and $8 \mu \mathrm{g} / \mathrm{mL}$ in the $\mathrm{L}$ group, the amphotericin B showed MIC rates between 0.25 and $4 \mu \mathrm{g} / \mathrm{mL}$ in the $\mathrm{H}$ group and in the $\mathrm{S}$ group and between 0.25 and $16 \mu \mathrm{g} / \mathrm{mL}$ in the L group. Finally, the flucytosine had MIC rates $<1 \mu \mathrm{g} / \mathrm{mL}$ in all groups.

\section{Discussion}

The Vitek ${ }^{\circledR}$ MS -Mass spectrometry (bioMérieux) is used for microbial identification being the first and unique mass spectrometer of America approved and certificated by the FDA for the in vitro diagnose use. Therefore, beyond being the only system register and approved by the ANVISA for this purpose, now has the certificate and the seal of the FDA (FDA, 2001). 
The Vitek ${ }^{\circledR} 2$ Compact system is a practical and efficient tool used widely by researches for microbial identification (Melhen et al., 2014; Pereira, 2010; Silva et al., 2013; Zhang et al., 2014).

The Vitek ${ }^{\circledR} 2$ Compact device monitors the microbial kinetic growth and calculates the respective MIC by an own algorithm used in the susceptibility evaluation against antifungal drugs. Based on the MIC values during the performed assays, these can be compared in a data base containing an average distribution of these concentrations (Joyanes et al., 2001; Pasteran et al., 2011; Soloaga, 2010). The afore mentioned device acts as an useful, accurate and quickly tool in the profile susceptibility detection of microorganisms, helping in the use of prescription and dosage of antibiotics for fungemias (Terasawa, 2006).

These results are similar to the ones found by Crocco et al. (2004) and by Gomes et al. (2010), where the susceptibility of Candida spp. was analyzed, showing that the species studied in this genus were susceptible to the amphotericin B with a MIC of $<0.5 \mu \mathrm{g} / \mathrm{mL}$. Meanwhile the fluconazole MICs varied from 0.12 to $4 \mu \mathrm{g} / \mathrm{mL}$, and the antifungals itraconazole and voriconazole presented MICs of $<0.03 \mu \mathrm{g} / \mathrm{mL}$.

In the present study, the microorganisms showed a high resistance against Fluconazole $(26.6 \%)$ and an intermediate susceptibility $(12.2 \%)$, as described by Favalessa et al. (2010) attributing the highest Minimum Inhibitory Concentration (MIC) values to the fluconazole, which demonstrates a high resistance in the isolates of Candida spp. to this drug. In the susceptibility pattern (method M27-A3 CLSI, 2008), the species: C. albicans, C. tropicalis and C. parapsilosis were considered susceptible to antifungals such as the amphotericin B and to the fluconazole (Rex et al., 2000). The fluconazole is known for having low incidence of collaterals effects (compared to the imidazoles) and high activity against most of the Candida spp., with the exception of C. krusei and C. glabrata (Klastersky, 2004). The amphotericin $\mathrm{B}$, who belongs to the polyene antifungals, is one of the principal drugs of election available for the treatment of invasive fungal infections. However, collateral effects such as nephrotoxicity, dyspnea, hives, chest and abdominal pain and hypoxemia are associated (Oliveira et al., 2016; Lumbreras et al., 2003; Walsh et al., 2002).

The antifungal resistance in yeasts, like any other microorganism, can be classified as intrinsic resistance, natural resistance and acquired resistance. The intrinsic resistance is characterized when all the specie members' are resistant to certain drug or a class of antifungal agent before drug exposure, this is due to genetic expression of this condition. The natural resistance is characterized when some particular kind of strains exhibit resistance. Meanwhile the acquired resistance is developed in response to the drug exposure (Leão et al., 2004; Santos, 2009). The fluconazole is a drug which is known for having a potential action against yeasts from the Candida genera. However the repetitive and prolonged fluconazole use in immunologically compromised patients can developed resistance against this fungi.

Many resistance mechanisms are well known, such as the intrinsic fluconazole resistance expressed by isolates of C. krusei and C. glabrata (Borowicz et al., 2012), which can explain the higher resistance to this drug, in the present study.

Martins et al. (2010) obtained similar values of those observed in the present study. In such study, they analyzed the antifungal susceptibility of Candida spp. obtained from patients with onychomycosis, having $99 \%$ of susceptibility against the amphotericin $\mathrm{B}$.

With susceptibility values similar to the amphotericin B (Klepser and Lewis, 2002), the voriconazole was developed at the final period of the 80 s decade and its origin was from the idea of obtaining a drug with a broader spectrum action than the fluconazole. The fluconazole has a high antifungal potential against a wide variety of fungi, such as Candida spp. Aspergillus spp., Scedosporium spp. and Fusarium spp. (Donnelly and De Pauw, 2004).

Beyond that, its action is more efficient against emergent pathogens, compared to other azoles drugs (Zhang et al., 2014). The flucytosine is efficient in yeasts infections despite of having a short action spectrum, yet susceptible in $100 \%$ of the samples tested. The $96.7 \%(n=1.202)$ of the isolates were correctly identified at the species level and $0.2 \%(\mathrm{n}=2)$ of the isolates were identified at the genera level, meanwhile the $2.4 \%(n=30)$ of the isolates were not identified by the 2.0 Vitek $^{\circledR}$ MS system, (Zhang et al., 2014), confirming its reliability in the identification.

The four antifungal drugs studied showed different susceptibilities against the yeasts species, wherein fluconazole presented a higher resistance against the three isolated origins, followed by the amphotericin B and the voriconazole, meanwhile the flucytosine presented efficiency against all yeasts present in this study, none of the yeasts showed resistance to the flucytosine. The fact that the Fluconazole had a higher resistance can be associated with the reason of being a drug commonly used mainly in human.

The human's isolated yeasts presented a higher resistance to the tested drugs than the yeasts isolated from wild animals. Which can occur due to the higher drug exposure in human compared to the animals who live isolated in wild environment and most of the cases never had contact with any kind of drugs.

These results also demonstrate the need of susceptibility characterization of the yeasts against the antifungal drugs before any antimicrobial therapy use, in order to avoid the microorganism's resistance and the drug overdose.

\section{References}

AL-SWEIH, N., KHAN, Z., KHAN, S. and DEVARAJAN, L.V., 2009. Neonatal candidemia in Kuwait: a 12- year study of risk factors, species spectrum and antifungal susceptibility. Mycoses, vol. 52, no. 6, pp. 518-523. PMid:18983425. http:// dx.doi.org/10.1111/j.1439-0507.2008.01637.x. 
BIOMÉRIEUX, 2008. Vitek $2^{\mathrm{TM}}$ : Instrument user manual. Durham: bioMérieux, no. 1, pp. 185-226.

BOROWICZ, K.K., PISKORSKA, B., STĘPNIAK, B. and CZUCZWAR, S.J., 2012. Effects of fluoxetine on the anticonvulsant action of valproate and ethosuximide in mouse model of myoclonic convulsions. Annals of Agricultural and Environmental Medicine, vol. 19, no. 3, pp. 487-490. PMid:23020044.

CLINICAL AND LABORATORY STANDARS INSTITUTE CLSI, 2008. M27-A3: Reference method for broth dilution antifungal susceptibility testing of yeasts - approved standard-third edition. 3rd ed. Wayne, PA: Clinical and Laboratory Standars Institute.

CLINICAL AND LABORATORY STANDARS INSTITUTE - CLSI, 2012. M27-S4: Reference method for broth dilution antifungal testing of yeats; fourth informal supplement. Wayne, PA: Clinical and Laboratory Standars Institute.

COLEMAN, M.P., QUARESMA, M., BERRINO, F., LUTZ, J.M., DE ANGELIS, R., CAPOCACCIA, R., BAILI, P., RACHET, B., GATTA, G., HAKULINEN, T., MICHELI, A., SANT, M., WEIR, H.K., ELWOOD, J.M., TSUKUMA, H., KOIFMAN, S., E SILVA, G.A., FRANCISCI, S., SANTAQUILANI, M., VERDECCHIA, A., STORM, H.H. and YOUNG, J.L., and the CONCORD Working Group, 2008. Cancer survival in five continents: a worldwide population-based study. The Lancet Oncology, vol. 9, no. 8, pp. 730-756. PMid:18639491. http:// dx.doi.org/10.1016/S1470-2045(08)70179-7.

COLOMBO, A.L. and GUIMARÃES, T., 2007. Candidúria: uma abordagem clínica e terapêutica. Revista da Sociedade Brasileira de Medicina Tropical, vol. 40, no. 3, pp. 332-337. PMid:17653471. http://dx.doi.org/10.1590/S0037-86822007000300016.

CROCCO, E.L., MIMICA, L.M.J., MURAMATU, L.H., GARCIA, C., SOUZA, V.M., RUIZ, L.R.B., and ZAITZ, C., 2004. Identificação de espécies de Candida e susceptibilidade antifúngica in vitro: estudo de 100 pacientes com candidíases superficiais. Anais Brasileiros de Dermatologia, vol. 79, no. 6, pp. 689-697. http://dx.doi.org/10.1590/S0365-05962004000600005.

DONNELLY, J.P. and DE PAUW, B.E., 2004. Voriconasole a new therapeutic agent with an extended spectrum of antifungal activity. Clinical Microbiology and Infection: The Official Publication of the European Society of Clinical Microbiology and Infectious Diseases, vol. 10, no. 1, suppl. 1, pp. 107-117. PMid:14748807. http://dx.doi.org/10.1111/j.1470-9465.2004.00838.x.

FAVALESSA, O.C., MARTINS, M.A. and HAHN, R.C., 2010. Aspectos micológicos e suscetibilidade in vitro de leveduras do gênero Candida em pacientes HIV-positivos provenientes do Estado de Mato Grosso. Revista da Sociedade Brasileira de Medicina Tropical, vol. 43, no. 6, pp. 673-677. PMid:21181021. http://dx.doi.org/10.1590/S0037-86822010000600014.

GALLE, L.C. and GIANINNI, M.J.S.M., 2009. Prevalence and susceptibility of vaginal yeast. Jornal Brasileiro de Patologia, vol. 40 , no. 3, pp. 229-236.

GOMES, L.C., CAVALCANTE, J.E., CUNHA, F.A., AMORIM, L.N. and MENEZES, A.E., 2010. Identification and susceptibility profile of Candida spp. isolated from urine of patients with Candiduria em Iguatu-Ceará. Revista Brasileira de Analises Clinicas, vol. 42, no. 3, pp. 223-225.

HÖFLING, J.F., ANIBAL, P.C., OBANDO-PEREDA, G.A., PEIXOTO, I.A.T., FURLETTI, V.F., FOGLIO, M.A. and GONÇALVES, R.B., 2010. Antimicrobial potential of some plant extracts against Candida species. Brazilian Journal of Biology $=$ Revista Brasileira de Biologia, vol. 70, no. 4, pp.
1065-1068. PMid:21180915. http://dx.doi.org/10.1590/S151969842010000500022

JOYANES, P., DEL CARMEN CONEJO, M., MARTÍNEZMARTÍNEZ, L. and PEREA, E.J., 2001. Evaluation of the VITEK 2 System for the Identification and Susceptibility Testing of Three Species of Nonfermenting Gram-Negative Rods Frequently Isolated from Clinical Samples. Journal of Clinical Microbiology, vol. 39, no. 9, pp. 3247-3253. PMid:11526158. http://dx.doi.org/10.1128/ JCM.39.9.3247-3253.2001.

KLASTERSKY, J., 2004. Empirical antifungal therapy. International Journal of Antimicrobial Agents, vol. 23, no. 2, pp. 105-112. PMid:15013034. http://dx.doi.org/10.1016/j.ijantimicag.2003.11.002.

KLEPSER, M. and LEWIS, R.,E. 2002. Antifungal pharmacodynamics. In: C.H. NIGHTINGALE, ed. Antimicrobial pharmacodynamics in theory and clinical practice. New York: MacGraw Hill. pp. 315-326.

LEÃO, R.E., GUIMARÃES, R.I., INÁCIO, M.C.C., FERREIRA, W.M. and CARDOSO, C.G., 2004. Aspects of the yeast Candida linked to nosocomial infections. NewsLab, vol. 64, no. 1, pp. 106-128.

LUMBRERAS, C., LIZASOAIN, M. and AGUADO, J.M., 2003. Antifúngicos de uso sistémico. Enfermedades Infecciosas y Microbiologia Clinica, vol. 21, no. 7, pp. 366-379, quiz 380, 390. PMid:14525693. http://dx.doi.org/10.1016/S0213-005X(03)72964-4.

MARTINS, M., HENRIQUES, M., RIBEIRO, A.P., FERNANDES, R., GONÇALVES, V., SEABRA, A., AZEREDO, J. and OLIVEIRA, R., 2010. Oral Candida carriage of patients attending a dental clinic in Braga, Portugal. Revista Iberoamericana de Micologia, vol. 27, no. 3, pp. 119-124. PMid:20403455. http://dx.doi.org/10.1016/j. riam.2010.03.007.

MELHEM, M.S., BERTOLETTI, A., LUCCA, H.R., SILVA, R.B., MENEGHIN, F.A. and SZESZS, M.W., 2014. Use of the VITEK 2 system to identify and test the antifungal susceptibility of clinically relevant yeast species. Brazilian Journal of Microbiology, vol. 44, no. 4, pp. 1257-1266. PMid:24688520. http://dx.doi.org/10.1590/ S1517-83822014005000018.

MOKADDAS, E.M., AL-SWEIH, N.A. and KHAN, Z.U., 2007. Species distribution and antifungal susceptibility of Candida bloodstream isolates in Kuwait: a 10-year study. Journal of Medical Microbiology, vol. 56, no. Pt2, pp. 255-259. PMid:17244809. http://dx.doi.org/10.1099/jmm.0.46817-0.

OLIVEIRA, V.M., CARRAROA, E., AULER, M.E. and KHALILC, N.M., 2016. Quercetin and rutin as potential agents antifungal against Cryptococcus spp. Brazilian Journal of Biology $=$ Revista Brasileira de Biologia, vol. 76, no. 4, pp. 1029-1034. PMid:27166572. http://dx.doi.org/10.1590/1519-6984.07415.

PASTERAN, F., LUCERO, C., SOLOAGA, R., RAPOPORT, M. and CORSO, A., 2011. Can we use imipenem and meropenem Vitek 2 MICs for detection of suspected KPC and other-carbapenemase producers among species of Enterobacteriaceae? Journal of Clinical Microbiology, vol. 49, no. 2, pp. 697-701. PMid:21159944. http:// dx.doi.org/10.1128/JCM.01178-10.

PEREIRA, A.P.V., 2010. Identificação Molecular de Candidoses Invasivas no Centro Hospitalar Cova da Beira, E.P.E: Métodos Convencionais vs. Métodos Moleculares. Portugal: Universidade Nova de Lisboa, 129 p. Dissertação de Mestrado em Ciências Biomédicas.

PFALLER, M.A., MOET, G.J., MESSER, S.A., JONES, R.N. and CASTANHEIRA, M., 2011. Candida bloodstream infections: 
comparison of species distributions and antifungal resistance patterns in community-onset and nosocomial isolates in the SENTRY Antimicrobial Surveillance Program, 2008-2009. Antimicrobial Agents and Chemotherapy, vol. 55, no. 2, pp. 561566. PMid:21115790. http://dx.doi.org/10.1128/AAC.01079-10.

REX, J.H., WALSH, T.J., SOBEL, J.D., FILLER, S.G., PAPPAS, P.G., DISMUKES, W.E. and EDWARDS, J.E., and the Infectious Diseases Society of America, 2000. Practice guidelines for the treatment of candidiasis. Clinical Infectious Diseases: An Official Publication of the Infectious Diseases Society of America, vol. 30, no. 4, pp. 662-678. PMid:10770728.

SANDVEN, P., 2000. Epidemiology of candidemia. Revista Iberoamericana de Micologia, vol. 17, no. 3, pp. 73-81. PMid:15762797.

SANTOS, L.S., 2009. Sensitivity profile of isolates from cases of hospital to conventional antifungal candidúrias. In: Anais do XIII Encontro Latino-Americano de Iniciação Científica e IX Encontro Latino Americano de Pós-Graduação, 5-11 Outubro 2009, São José dos Campos, Brasil. São José dos Campos: Universidade do Vale do Paraíba, pp. 1-5.

SILVA, G.A., BRANDÃO, D.F., VIANNA, E.O., SÁ-FILHO, J.B.C. and BADDINI-MARTINEZ, J., 2013. Cryptococcosis, silicosis, and tuberculous pseudotumor in the same pulmonary lobe. Jornal Brasileiro de Pneumologia, vol. 39, no. 5, pp. 620-626. PMid:24310636. http://dx.doi.org/10.1590/S180637132013000500013 .

SOLOAGA, R., 2010. Susceptibility Test Kit Analysis. In: Anais do $1^{\circ}$ Encontro de Usuários Vitek, 15-19 Março 2010, São Paulo, Brasil. São Paulo: Biomeuriuex, pp. 19-24.

SPELLBERG, B.J., FILLER, S.G. and EDWARDS JUNIOR, J.R., 2006. Current Treatment Strategies for Disseminated Candidiasis. Clinical Infectious Diseases, vol. 42, no. 2, pp. 244-251. PMid:16355336.
TERASAWA, L.B., 2006. Caracterização da resistência à oxacilina em estafilococos coagulase negativa isolados no hospital de clínicas de Curitiba - Paraná. Curitiba: Universidade Federal do Paraná, 92 p. Dissertação de Mestrado em Microbiologia, Parasitologia e Patologia, Setores de Ciências Biológicas e da Saúde.

TRABULSI, L.R. and TOLEDO, M.R.F., 1991. Microbiologia. 2nd ed. Rio de Janeiro: Atheneu. 780 p.

U. S. FOOD AND DRUG ADMINISTRATION - FDA, 2001 [viewed 18 May 2013]. Background document for the Antiviral Drug Products Advisory Committee Meeting October 4, 2001: Voriconazole tablets and voriconazole injection. Pfizer Global Research \& Development NDAs 21-66 and 21-267 [online]. Available from: https://www.fda.gov/ohrms/dockets/ac/01/ briefing/3792b2_02_FDA-voriconazole.pdf.

WALSH, T.J., PAPPAS, P., WINSTON, D.J., LAZARUS, H.M., PETERSEN, F., RAFFALLI, J., YANOVICH, S., STIFF, P., GREENBERG, R., DONOWITZ, G., SCHUSTER, M., REBOLI, A., WINGARD, J., ARNDT, C., REINHARDT, J., HADLEY, S., FINBERG, R., LAVERDIÈRE, M., PERFECT, J., GARBER, G., FIORITONI, G., ANAISSIE, E. and LEE, J., and the National Institute of Allergy and Infectious Diseases Mycoses Study Group, 2002. Voriconazole compared with liposomal amphotericin B for empirical antifungal therapy in patients with neutropenia and persistent fever. The New England Journal of Medicine, vol. 346, no. 4, pp. 225-234. PMid:11807146. http://dx.doi.org/10.1056/ NEJM200201243460403.

ZHANG, L., XIAO, M., WANG, H., GAO, R., FAN, X., BROWN, M., GRAY, T.J., KONG, F. and XU, Y.C., 2014. Yeast identification algorithm based on use of the Vitek MS system selectively supplemented with ribosomal DNA sequencing: proposal of a reference assay for invasive fungal surveillance programs in China. Journal of Clinical Microbiology, vol. 52, no. 2, pp. 572577. PMid:24478490. http://dx.doi.org/10.1128/JCM.02543-13. 